\title{
Comparison of Assays for Gap Junctional Communication Using Human Embryocarcinoma Cells Exposed to Dieldrin ${ }^{1}$
}

\author{
R. Loch-Caruso, ${ }^{2}$ V. Caldwell, M. Cimini, ${ }^{3}$ And D. Juberg \\ Toxicology Program, Department of Environmental and Industrial Health. \\ The University of Michigan, Ann Arbor, Michigan 48109-2029
}

Received June 1. 1989; accepted January 30, 1990

\begin{abstract}
Comparison of Assays for Gap Junctional Communication Using Human Embryocarcinoma Cells Exposed to Dieldrin. Loch-Caruso, R., Caldwell, V., Cimini, M., And Juberg, D. (1990). Fundam. Appl. Toxicol. 15, 63-74. Several assays were compared for their ability to detect inhibition of gap junctional communication in human embryocarcinoma cells exposed to the pesticide dieldrin. Included in this evaluation was a recently developed assay based on the transfer of the fluorescent dye derived metabolically from 5(and 6)-carboxy-2,7-dichlorofluorescein diacetate. This assay was compared to assays for fluorescence return after photobleaching (FRAP), transfer of Lucifer yellow after scrape-loading, autoradiographic visualization of $\left[{ }^{3} \mathrm{H}\right]$ uridine nucleotide transfer, and metabolic coupling of 6-thioguanine (6-TG) metabolites. The scrape-loading assay was the most sensitive assay, detecting inhibition of junctional communication at all concentrations tested. Additionally, the scrape-loading assay provided the clearest demonstration of concentration-dependent inhibition of junctional communication, although the [ $\left.{ }^{3} \mathrm{H}\right]$ uridine assay also showed significant concentration-related effects. The 5(and 6)-carboxy-2,7-dichlorofluorescein diacetate and 6-TG metabolic coupling assays detected significant inhibition at the two highest concentrations of dieldrin only. The FRAP assay also detected substantial inhibition at the two highest concentrations only. These results show that scrapeloading is the most sensitive assay of those compared in this study for the detection of inhibited junctional communication. Furthermore, compared to the other assays evaluated, the newly developed 5(and 6)-carboxy-2,7-dichlorofluorescein diacetate assay is at least as sensitive, yet less cumbersome, less expensive, and more rapid. Finally, the results show that each of these assays was easily applied to embryonic cells, suggesting that they may be useful for evaluating disruption of junctional communication in embryonic cell cultures. C1 1990 Society of Toxicology.
\end{abstract}

Gap junctional communication allows the direct cell-to-cell transfer of low-molecularweight substances (Loewenstein, 1979). This form of intercellular communication is initially observed in mammalian embryos at the late eight-cell preimplantation stage of development (Lo and Gilula, 1979; Goodall and John-

\footnotetext{
' A portion of this study was presented at the 28th Annual Meeting of the Teratology Society in West Palm Beach, FL, June 12-15, 1988 (Teratology 37, 475, 1988).

${ }^{2}$ To whom correspondence should be addressed.

${ }^{3}$ Present address: The Upjohn Co., Cardiovascular Diseases Research, Kalamazoo, MI 48007.
}

son, 1982) and persists into adulthood, where it is observed in most tissues. Accumulating evidence suggests that gap junctional communication may play a vital role in morphogenesis (Warner and Lawrence, 1982; Weir and Lo, 1982, 1984; Blennerhassett and Caveney, 1984; Warner et al., 1984; Fraser et al., 1987; Lee et al., 1987; Bevilacqua et al., 1990), and it has been suggested that alteration of junctional communication patterns could contribute to abnormal development (Loch-Caruso and Trosko, 1985; Welsch et al., 1987).

In the present study, we applied several assays of gap junctional communication to em- 
bryonic cells in culture, in order to compare the relative utility of the assays for the study of disruption of communication by toxicants. We chose to work with a human embryocarcinoma cell line (Huberman et al., 1984) because the cells are of human embryonic origin, have in vitro growth and seeding characteristics that render them easy to work with in each of the assays, and a 6-thioguanine (6TG)-resistant mutant, necessary for the 6-TG metabolic coupling assay, had been isolated from the parent cell line (Kavanagh et al., 1986). The pesticide dieldrin was used because previous studies indicated that it inhibitcd junctional communication at noncytotoxic concentrations in the embryocarcinoma cell line (Zhong-Xiang et al., 1986). Additionally, teratogenic and embryolethal effects were reported following single, high doses of dieldrin (Oltolenghi et al., 1974); however, Chernoff et al. (1975) were unable to confirm the teratogenicity findings when dieldrin was administered in multiple doses.

Five assays were compared for the detection of inhibition of junctional communication: fluorescence return after photobleaching (FRAP) (Wade et al., 1986), Lucifer yellow transfer after scrape-loading (El-Fouly et al., 1987), 6-TG metabolic coupling (Yotti et al., 1979; Trosko et al., 1985), autoradiographic visualization of $\left[{ }^{3} \mathrm{H}\right]$ uridine nucleotide transfer (Pitts and Simms, 1977), and an assay recently developed in our laboratory, transfer of the fluorescent dye derived metabolically from 5(and 6)-carboxy-2,7-dichlorofluorescein diacetate (CDCFDA). Under the experimental conditions used, the scrapeloading assay was the most expedient procedure and demonstrated the greatest sensitivity and ability to detect concentration-dependent inhibition. While not as sensitive as scrape-loading, the newly developed CDCFDA assay was more rapid and less expensive than the 6-TG metabolic coupling, $\left[{ }^{3} \mathrm{H}\right]$ uridine, and FRAP procedures. The CDCFDA assay may therefore serve as a useful alternative in experiments where the scrape-loading assay cannot be applied or where confirma- tion with a second assay is desired. Because the scrape-loading and CDCFDA assays are easily applied to embryonic cells, they may be particularly useful for studying disruption of gap junctional communication by developmental toxicants.

\section{MATERIALS AND METHODS}

Chemicals. Dieldrin (99\%+ pure) was a gift from Dr. B. V. Madhukar (Michigan State University) and was prepared in absolute ethanol as a $5 \mathrm{~mm}$ stock solution. The dieldrin was stored, handled, and disposed of in accordance with the hazardous chemical guidelines of The University of Michigan. The dyes, 5(and 6)-carboxyfluorescein diacetate (CFDA), CDCFDA, and Lucifer yellow $\mathrm{CH}$, were purchased from Molecular Probes (Eugene, OR). Stock solutions of CDCFDA and CFDA were prepared in $10 \mathrm{~mm}$ concentrations in dimethyl sulfoxide and stored refrigerated. Lucifer yellow $\mathrm{CH}$ was prepared as a $0.05 \%(\mathrm{w} / \mathrm{v})$ solution in calcium- and magnesiumfree Dulbecco's phosphate-buffered saline (CMF-PBS) (Dulbecco and Vogt, 1954) and stored refrigerated. Fluorescein-conjugated latex beads (Fluoresbrite carboxylate microspheres, ca. $1.0 \mu \mathrm{m}$ in diameter) were purchased from Polysciences (Warrington, PA). 6-Thioguanine was purchased from Sigma Chemical Co. (St. Louis, $\mathrm{MO})$ and stored frozen as a stock solution $(1 \mathrm{mg} / \mathrm{ml})$ in sterile water.

Cell culture. The human embryocarcinoma (IT) cells were a gift from Dr. J. E. Trosko (Michigan State University). The HT cell line was originally isolated from PA-1 cells (Zeuthen et al., 1980) by Huberman et al. (1984) and has a pseudodiploid karyotype $(46, X X, t[15: 20])$. The 6-TG resistant $\left(6-\mathrm{TG}^{\mathrm{r}}\right)$ cells used in the metabolic coupling assay were cloned from X-irradiated wild-type HT cells (Kavanagh et al., 1986) and were also a gift from Dr. Trosko.

The cells were maintained in growth medium containing Eagle's salts (Eagle, 1959) supplemented with a 50\% increase of vitamins and essential amino acids except glutamine, a $100 \%$ increase of nonessential amino acids, $1 \mathrm{mM}$ sodium pyruvate, $5.55 \mathrm{~mm}$ D-glucose. $14.3 \mathrm{~mm}$ sodium chloride, $11.9 \mathrm{~mm}$ sodium bicarbonate, and $5 \%$ fetal bovine serum. The cells were incubated in humidified air containing $5 \% \mathrm{CO}_{2}$ and subcultured after trypsin digestion as needed to avoid confluence. Routine screening with the fluorescent dye Hoechst 33258 verified that cells were free of mycoplasma (Chen. 1977).

$C D C F D A$ dye transfer assay. Cultures of dye-donor and dye-recipient cells were prepared separately, then cocultured for sufficient time to allow cell attachment and dye transfer. The recipient cells were unlabeled and the donor cells were double-labeled with fluorescent latex beads (Mosser and Bols, 1982) and fluorescent dye (Rot- 
man and Papermaster, 1966). The fluorescent dye was capable of junctional transfer, while the latex beads were too large to pass through the channels of gap junctions; the beads thus served to distinguish dye-donor from dyerecipient cells.

To prepare cultures of recipient cells, HT cells were seeded at a density of $9 \times 10^{4}$ cells per 60 -mm tissue culture dish (Corning) and incubated overnight (16-18 hr) at $37^{\circ} \mathrm{C}$ in a humidified $5 \% \mathrm{CO}_{2}$ atmosphere. To prepare the dye-donor cells, latex beads were added to subconfluent cultures at a final density of $2.5 \times 10^{6}$ beads $/ \mathrm{cm}^{2}$ growth surface area. During the overnight incubation, the cells phagocytized the beads, which were then retained throughout the experiment. After overnight incubation, the donor cells were rinsed with Dulbecco's phosphate-buffered saline (PBS) (Dulbecco and Vogt, 1954) to remove unincorporated beads, then loaded with fluorescent dye by incubation for $10 \mathrm{~min}$ with $15 \mu \mathrm{M}$ membrane permeant acetoxy ester parent compound, CDCFDA, in PBS containing $1 \mathrm{mg}$ glucose/ml (PBSG). Within the cell, cytoplasmic esterases removed the acetate groups to form the hydrophilic fluorochrome, 5(and 6)-carboxy-2,7-dichlorofluorescein (CDCF) (Rotman and Papermaster, 1966). The cultures were rinsed three times with PBSG to remove unincorporated and surfacebound dye. The cells were harvested with trypsin, pelleted by low-speed centrifugation, and resuspended in fresh medium. A sample of the cell suspension was counted with a hemacytometer.

The dye-donors were added to the unlabeled, dye-recipient cell cultures at a density of $4.5 \times 10^{4}$ cells per dish along with fresh medium containing ethanol (solvent controls) or dieldrin. The cocultures were incubated 30 min to $3 \mathrm{hr}$ to determine the duration of incubation necessary for donor cell attachment, spreading, formation of permeable junctions, and dye transfer. Since maximum levels of dye transfer reached a plateau by $2.5 \mathrm{hr}$ of coculture (Fig. 1A), this duration of incubation was used in six subsequent experiments, although $3.5 \mathrm{hr}$ of coculture were allowed in two experiments with no significant differences in results. After coculture, the medium was replaced with ice-cold PBSG and the appropriate amount of test substance. The plates were put on ice until they were scored for dye transfer. Replacement of the medium with ice-cold PBSG retards the establishment of additional dye-coupling (unpublished observation).

The plates were scored for dye transfer by the examination of 100 donor-recipient cell contacts at $400 \times$ magnification using a Nikon Diaphot-TMD microscope equipped with a TMD-EF epifluorescence unit and appropriate filters for CDCF fluorescence (excitation wavelength $450-490 \mathrm{~nm}$ with a $520-\mathrm{nm}$ barrier filter). The donor-recipient cell pairs were examined under bright-field conditions to verify cell-cell contact, then under fluorescence conditions for evidence of dye transfer. Because the fluorescence of the beads and that of the dye were spectrally similar, it was easy to distinguish donors and
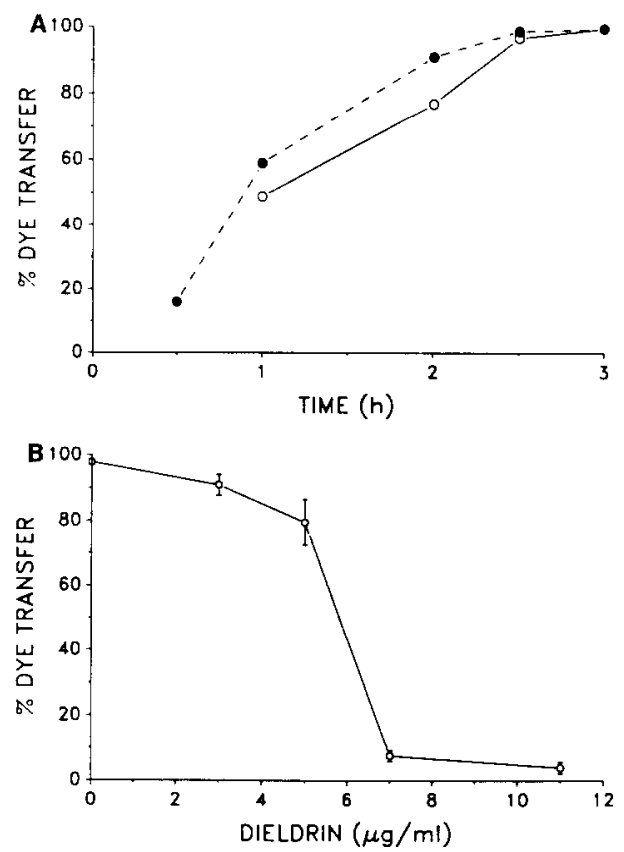

FIG. 1. Assay for fluorescent dye transfer using 5(and 6)-carboxy-2,7-dichlorofluorescein diacetate (CDCFDA). I ransfer was scored in 100 dye-donor-recipient pairs per dish. (A) Time course of dye transfer in untreated cultures: transfer achieved a plateau after $2.5 \mathrm{hr}$ in replicate experiments. (B) Inhibition of dye transfer in cultures exposed to dieldrin: significant inhibition was observed at 7 and $11 \mu \mathrm{g} / \mathrm{ml}(p<0.05)$; the data are plotted as the means \pm SEM of $8-11$ dishes.

recipients under the same filter conditions. In each treatment group, 8-11 dishes were scored in separate experiments.

Cytotoxicity was assessed in this assay by the ability of the donor cells to retain the fluorochrome throughout the coculture period (Bruning et al., 1980: McGinnes et al., 1986: Kolber et al., 1988). Cytotoxicity would be indicated by the presence of bead-labeled cells that lacked the cytoplasmic CDCF dye.

Autoradiographic visualization of $\left[{ }^{3} \mathrm{H}\right]$ uridine nucleotide transfer. In this procedure, $\left[{ }^{3} \mathrm{H}\right]$ uridine was employed to monitor the formation of communicating junctions in freshly plated cultures (Pitts and Simms, 1977). Intracellularly, $\left[{ }^{3} \mathrm{H}\right]$ uridine is phosphoribosylated to a small nucleotide that is able to pass through gap junctions. To perform the assay, donor cells double-labeled with $\left[{ }^{3} \mathrm{H}\right]$ uridine and nontransferrable fluorescent latex beads were mixed with unlabeled recipient cells. The recipient cells were seeded in $60-\mathrm{mm}$ tissue culture dishes at a density of $8 \times 10^{7}$ cells/dish the day prior to the experiment. Donor cells were preloaded with latex beads during a 16- to 18 -hr incubation with $2.5 \times 10^{6}$ beads/ 
$\mathrm{cm}^{2}$ growth surface area. Unincorporated beads were rinsed from the culture with PBSG, and the donors were loaded with $\left[{ }^{3} \mathrm{H}\right]$ uridine $(10 \mu \mathrm{Ci} / \mathrm{ml})$ during a 3 -hr incubation just prior to coculture with recipient cells. To coculture the cells, $2.5 \times 10^{5}$ donors were added to each recipient cell culture.

The dieldrin was diluted in medium immediately prior to addition to the cocultures, and the cells were incubated for $2.5 \mathrm{hr}$. After the transfer period, the cells were washed with PBS and fixed with $7 \%(w / v)$ trichloroacetic acid at $4^{\circ} \mathrm{C}$ for $30 \mathrm{~min}$. The dishes were rinsed with deionized water and allowed to dry. For autoradiography, the dishes were dipped in photographic emulsion, exposed in the dark at $4^{\circ} \mathrm{C}$ for 8-10 days, and developed with standard photographic developer and fixer. The culture dishes were examined under blue excitation (450-490 $\mathrm{nm}$ ) using a Nikon Diaphot-TMD microscope equipped with a TMD-EF epifluorescence unit and a 520-nm barrier filter. The dishes were alternately observed under fluorescence and bright field illumination to identify contacting donor-recipient pairs and scored for evidence of nucleotide transfer. Transfer was indicated by grains over touching cells, one of which was very darkly marked and contained fluorescent beads, indicating that it was the donor cell. A total of 100 donor-recipient cell contacts were scored in replicate cultures for each treatment group.

Fluorescence return after photobleaching. Cell cultures were prelabeled with CFDA, and the fluorescent dye was photobleached in selected cells. The photobleachcd cclls were then analyzed by fluorescence microscopy for return of fluorescence, presumably due to redistribution of the dye from adjoining cells via gap junctions (Wade $e t$ al., 1986).

The HT cells were grown in $35-\mathrm{mm}$ culture dishes to less than $50 \%$ confluence. Fresh medium containing ethanol (solvent controls) or dieldrin was added to each culture, which was then incubated for $1 \mathrm{hr}$. The medium was removed and the dishes were rinsed three times with PBSG. To load the dye, the cells were incubated with 10 $\mu \mathrm{M}$ CFDA in PBSG for $10 \mathrm{~min}$ followed by three rinses with PBSG. The cultures were maintained in PBSG containing the appropriate concentration of dieldrin or ethanol (controls).

For FRAP analysis, the individual dishes of labeled cells were placed on the computer-controlled microscope stage of the ACAS 470 workstation (Meridian Instruments, Okemos, MI). Three cells appropriate for the experiment were selected from a microscopic field, including two isolated cells and one cell in contact with other cells. The microscope stage moved the cells in a two-dimensional manner over an inverted epifluorescence microscope objective which focused an argon ion laser beam (488-nm wavelength) to a $1-\mu \mathrm{m}$ spot. The laser excited fluorescence in individual cells at $2.0-\mu \mathrm{m}$ steps in a two-dimensional raster pattern. The emitted intensities were color-coded and the digitized pseudocolor images of fluorescence distribution in the analyzed cells were recorded. The digital information was converted to numerical values of fluorescence intensity for the selected cells. The laser intensity was then significantly increased and a series of photobleaching pulses (ca. $1 \mu \mathrm{m}$ in diameter) was delivered to the contacting cell and one of the isolated cells. The third, unbleached cell served as a monitor of nonspecific dye fading during the procedure. Fluorescence imaging scans were performed at reduced laser intensity immediately after bleaching and at 5 and $10 \mathrm{~min}$ after bleaching. Data obtained from the FRAP experiments were converted to the percentage fluorescence intensity relative to prebleach levels. Three or four fields were evaluated in each treatment group.

Cytotoxicity in this assay was assessed by the ability of the cells to convert the CFDA to its fluorochrome (Jarnagin and Luchsinger, 1980; Jones and Senft, 1985; Jackson et al., 1985).

Scrape-loading. The scrape-loading procedure was a modification of that described by El-Fouly et al. (1987). The HT cells were grown to near confluence in $35-\mathrm{mm}$ culture dishes. The incubation medium was replaced with fresh medium containing ethanol (solvent controls) or dieldrin, and the cultures were incubated for 1 hr at $37^{\circ} \mathrm{C}$ in a humidified $5 \% \mathrm{CO}_{2}$ atmosphere. The medium was then removed, the cultures were rinsed three times with prewarmed CMF-PBS, and $1 \mathrm{ml}$ of a $0.05 \%$ solution of Lucifer yellow in CMF-PBS was added to each dish. The edge of a razor blade was pressed into the monolayer to form the "scrape line" along which the dye enters the cells. After $1 \mathrm{~min}$ the dye solution was removed and the cultures were rinsed three times with prewarmed PBS. The cultures remained in PBS for 15 min to allow dye transfer away from the scrape line. The PBS was then discarded and the cultures were fixed with approximately $2 \mathrm{ml} /$ dish of 3.7\% ( $/ \mathrm{v})$ formaldehyde in PBS for $15 \mathrm{~min}$ (Stewart. 1978). Each culture dish was rinsed three times with CMF-PBS and two drops of $90 \%(\mathrm{v} / \mathrm{v})$ glycerol were added to each fixed culture dish followed by a coverslip.

The culture dishes were examined under blue excitation (450-490 nm) using a Nikon Diaphot-TMD microscope equipped with a TMD-EF epifluorescence unit and a 520-nm barrier filter. A $10 \times 10$ square grid micrometer was placed in the eyepiece of the microscope. Fields were selected for analysis in an unbiased manner, using a ruler placed along the edge of the stage. The stage was advanced in $1-\mathrm{mm}$ increments along the ruler length, and for each field the culture dish was adjusted to a "best fit" line with the edge of the micrometer grid against the edge of the scrape line. The number of squares in the grid where fluorescence was detected was determined for each field. The squares directly on the edge of the scrape line were not included as these cells were predominantly loaded with the dye directly from the scraping. This procedure was applied to both sides of the scrape line. A total of 18 fields were scored in each dish in replicate experiments. 
Because Lucifer yellow is a membrane-impermeant dye, cytotoxicity was assessed by uptake of the dye in cells distant from the scrape line.

Metabolic coupling assay. The assay for metabolic coupling is based on transfer of the toxic metabolite of 6-TG from wild-type 6-TG sensitive cells to 6-TG ${ }^{r}$ cells (Yotti et al., 1979). In cocultures of wild-type and 6-TGr cells incubated in 6-TG-containing medium, cell survival and subsequent colony formation are limited to those $6-\mathrm{TG}^{\mathrm{r}}$ cells that fail to form communicating junctions with wild-type cells. Increased colony formation in medium containing a test substance can thus be used as an indicator of inhibited junctional communication. The assay was performed as described by Kavanagh et al. (1986) with minor modifications.

To perform the assay, the appropriate cell combinations were seeded into $60-\mathrm{mm}$ tissue culture dishes and allowed to attach before exposure to the dieldrin. To measure metabolic coupling, a mixture of 200 6-TG cells was seeded with $3 \times 10^{5}$ wild-type cells, densities that allowed ample cell contact and opportunity for metabolic coupling. As a measure of cytotoxicity, cell survival was determined in cocultures of $2006-\mathrm{TG}^{\mathrm{r}}$ cells and $10^{4}$ wild-type cells, a lower cell density that allowed negligible metabolic coupling. The control groups consisted of cocultures treated with ethanol (solvent) only. Plating efficiencies were obtained by growing 200 6-TG' cells per dish, and these data were compared to data from a group in which $2006-\mathrm{TG}^{\mathrm{r}}$ cells were grown with $10^{4}$ wild-type cells per dish. Negligible differences were observed between the mean colony formation values of these two groups (107.5 and 106.6, respectively). The colony count from the latter group was used to calculate the relative cell survivals and recoveries. The wild-type cell population was checked for spontaneous mutants by plating 3 $\times 10^{5}$ cells per dish in the presence of 6-TG, and no colony formation was observed. The growth media of all treatment groups contained 6-TG $(10 \mu \mathrm{g} / \mathrm{ml})$. There were eight plates per treatment group.

Dieldrin was added in $1 \mathrm{ml}$ of medium $4 \mathrm{hr}$ after the colls were seeded, followed $30 \mathrm{~min}$ later by the addition of $6-\mathrm{TG}(10 \mu \mathrm{g} / \mathrm{ml})$. The plates were changed to fresh medium containing 6-TG $(10 \mu \mathrm{g} / \mathrm{ml})$ after 3 days of incubation. After a total of 9 days the plates were stained with crystal violet and the number of colonies per plate was scored using a semiautomated colony counting system (VPC Systems, Ann Arbor, MI). Cell survivals and recoveries were then calculated as the percentage plating efficiency.

Statistical analysis. The data were analyzed by the $\chi^{2}$ or Kruskal-Wallis statistic, as appropriate (Gad and Weil, 1982), using Microstat software (Ecosoft. Indianapolis, $\mathrm{IN})$. When a significant $(p<0.05)$ effect was observed with the $\chi^{2}$ analysis, each treatment group was compared to the appropriate control group using the $\chi^{2}$ (large $n$ ) or Fisher's exact (small $n$ ) test and adjusting the significance level as described by Everitt (1977). Similar multiple comparisons were made when a significant effect $(p<0.05)$ was observed with the Kruskal-Wallis test. using the distribution-free multiple comparison tests described by Hollander and Wolfe (1973).

\section{RESULTS}

Junctional communication was determined in the scrape-loading assay by the extent of dye transfer away from the scrape line. Extensive dye transfer was observed in solvent controls (Fig. 2A, phase contrast; Fig. $2 \mathrm{~B}$, dark field), with a noticeable reduction of dye transfer observed at the lowest concentration of dieldrin, $3 \mu \mathrm{g} / \mathrm{ml}$ (Fig. $2 \mathrm{C}$, phase contrast; Fig. 2D, dark field). At the highest concentration, $11 \mu \mathrm{g}$ dieldrin $/ \mathrm{ml}$, no dye transfer was observed (Fig. 2E, phase contrast; Fig. $2 \mathrm{~F}$, dark field). Quantitatively, dye transfer after scrape-loading was markedly inhibited to less than $50 \%$ of control values at all concentrations of dieldrin, and the inhibition was concentration-dependent (Fig. 3, $p$ $<0.05$ ). The results were highly consistent between replicate experiments (Fig. 3). Dye uptake by cells distant from the scrape line was not observed, suggesting that cytotoxicity was minimal.

Dye transfer in the CDCFDA assay was indicated by the observation of dye in contacting bead-labeled donors and non-bead-labclcd rccipicnts, as seen in the solvent control culture shown in Figs. 4a (phase contrast) and $4 b$ (dark field). Figures $4 c$ (phase contrast) and $4 \mathrm{~d}$ (dark field) show an example of cells exposed to $5 \mu \mathrm{g}$ dieldrin $/ \mathrm{ml}$ in which no transfer was observed. Since no significant differences were observed between the experiments scored after $2.5 \mathrm{hr}$ and those scored after $3.5 \mathrm{hr}$ coculture, these data were combined in Fig. 1B. Some inhibition was observed at concentrations of $5 \mu \mathrm{g}$ dieldrin $/ \mathrm{ml}$ ( $79 \%$ of control value, n.s.), with near-maximal inhibition at 7 and $11 \mu \mathrm{g}$ dieldrin $/ \mathrm{ml}$ (Fig. 1B, $p<0.05$ ). Cytotoxicity was not observed at any of the concentrations tested, based on the ability of the bead-labeled donor cells to attach and retain the membrane-im- 

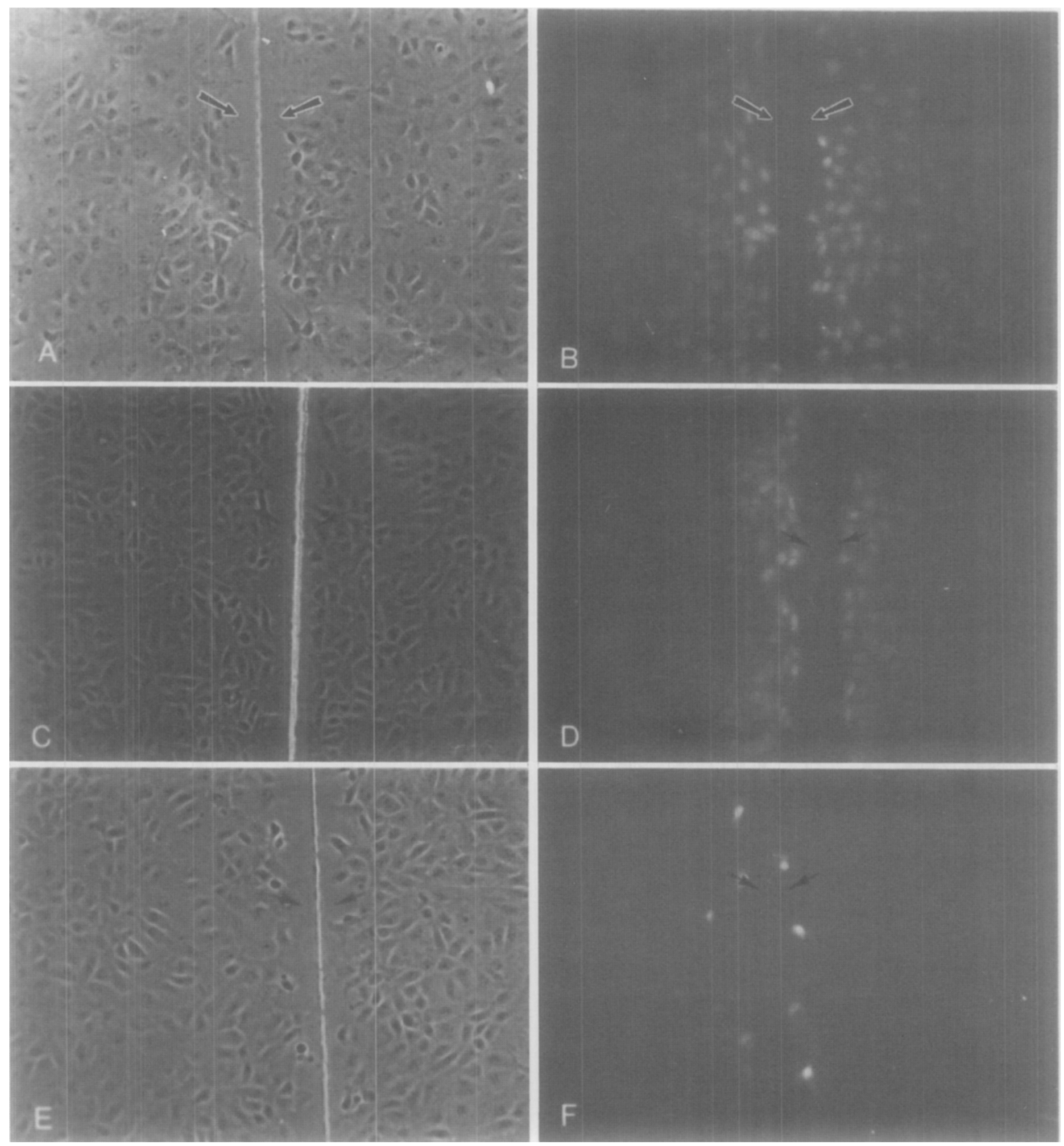

FIG. 2. Transfer of the fluorescent dye, Lucifer yellow, following scrape-loading. The scrape line is indicated by arrows. Solvent controls: (A) phase contrast, (B) dark field. Cultures exposed to $3 \mu \mathrm{g} \mathrm{dieldrin/ml:}$ (C) phase contrast, (D) dark field. Cultures exposed to $11 \mu \mathrm{g}$ dieldrin $/ \mathrm{ml}$ : (E) phase contrast, (F) dark field. $\times 93$.

permeant fluorescent dye during the coculture period.

The results of the $\left[{ }^{3} \mathrm{H}\right]$ uridine nucleotide transfer assay were similar to those of the CDCFDA assay except that statistically significant inhibition was observed at $5 \mu \mathrm{g}$ dieldrin/ $\mathrm{ml}$ (Table $1, p<0.05$ ), even though the inhibition ( $92 \%$ of control value) at this concentration was less than that observed with the
CDCFDA assay. Near-maximal inhibition was observed at 7 and $11 \mu \mathrm{g}$ dieldrin $/ \mathrm{ml}$ (Table $1, p<0.05$ ).

In the 6-TG metabolic coupling assay, inhibition of junctional communication was suggested by the increased recovery of 6-TG ${ }^{r}$ mutants in cocultures, which were significantly increased with exposure to 7 or $11 \mu \mathrm{g}$ dieldrin/ml (Fig. 5, $p<0.05$ ). Additionally, 


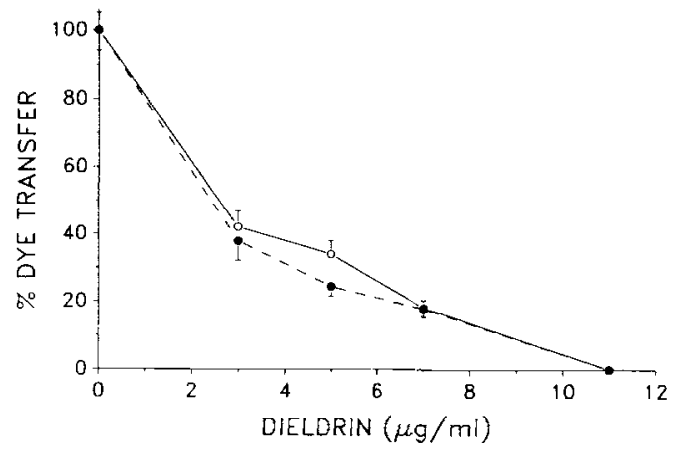

FIG. 3. Transfer of the fluorescent dye. Lucifer yellow, following scrape-loading in cultures exposed to dieldrin. The extent of transfer from the scrape line was determined with a micrometer and expressed as the mean $\perp$ SLM percentage dye transfer relative to controls. All values in the $11 \mu \mathrm{g} / \mathrm{ml}$ group were zero. A total of 18 microscopic fields per treatment were scored in replicate experiments. Significant inhibition of dye transfer was observed at all concentrations of dieldrin.

the responses at 7 and $11 \mu \mathrm{g}$ dieldrin/ $/ \mathrm{ml}$ were similar, although the degree of inhibition at these concentrations was only about $50 \%$ of control. In parallel cultures exposed to dieldrin, cytotoxicity was indicated by cell survival. Significant inhibition of cell survival was observed at both 7 and $11 \mu \mathrm{g}$ dieldrin $/ \mathrm{ml}$ $(p<0.05)$, with average values of 82 and $65 \%$ of control, respectively (Fig. 5). Because decreased cell survival was observed at the same concentrations at which increased recovery of 6-TG ${ }^{\mathrm{r}}$ cells was observed, the metabolic coupling data may be confounded by altered cell densities due to cytotoxicity. Nonetheless, it would be predicted that altered cell density alone could not account for the magnitude of the effect observed at $7 \mu \mathrm{g}$ dieldrin $/ \mathrm{ml}$.

While the FRAP assay appeared to discriminate between the different dieldrin exposures, the FRAP response in contacting cells was highly variable (Fig. 6). A significant concentration effect was detected at $10 \mathrm{~min}$ post-scan (Fig. 6, $p<0.05$ ), but post-hoc analyses failed to detect significant differences between any exposure level and controls at $p<0.05$. Statistical significance was achieved between the control and the $11 \mu \mathrm{g}$ dieldrin/ml group at $p<0.10$. It should be noted that Hollander and Wolfe (1973) have suggested that the conservative nature of the distribution-free multiple comparison posthoc test, recommended for these types of data, may warrant the use of $p$ values greater than 0.05 . Nonetheless, it is apparent from inspection of Fig. 6 that the high degree of variability contributed to the relatively poor discrimination between treatment groups. No FRAP was observed in isolated photobleached cells, indicating that the FRAP observed in contacting cells was cell contact dependent. However, substantial decreases in relative fluorescence were detected in some isolated unbleached cells, with values ranging from 62 to $93 \%$ of prebleach values. This suggests that uncontrolled photobleaching may have contributed to the variability observed. Dieldrin exposure did not alter the ability of the cells to metabolize the parent compound to the fluorochrome, suggesting that cytotoxicity was minimal.

\section{DISCUSSION}

Each assay detected significant inhibition of junctional communication by dieldrin, but only scrape-loading was able to detect inhibition at the lowest concentration tested. Additionally, the scrape-loading assay was the only one to clearly discriminate between intermediate levels of inhibition at different concentrations of dieldrin. With both the CDCFDA and the $\left[{ }^{3} \mathrm{H}\right]$ uridine assays, inhibition was slight (although statistically signifcant in the $\left[{ }^{3} \mathrm{H}\right]$ uridine assay) at $5 \mu \mathrm{g}$ dieldrin/ $\mathrm{ml}$, but was nearly total at 7 and $11 \mu \mathrm{g} / \mathrm{ml}$. The FRAP data were highly variable, obscuring differences between treatments.

From a different perspective, these data suggest that the CDCFDA, $\left[{ }^{3} \mathrm{H}\right]$ uridine, metabolic coupling, and FRAP assays may be more sensitive to the presence of communicating junctions compared to the scrapeloading assay, exhibiting high response levels 

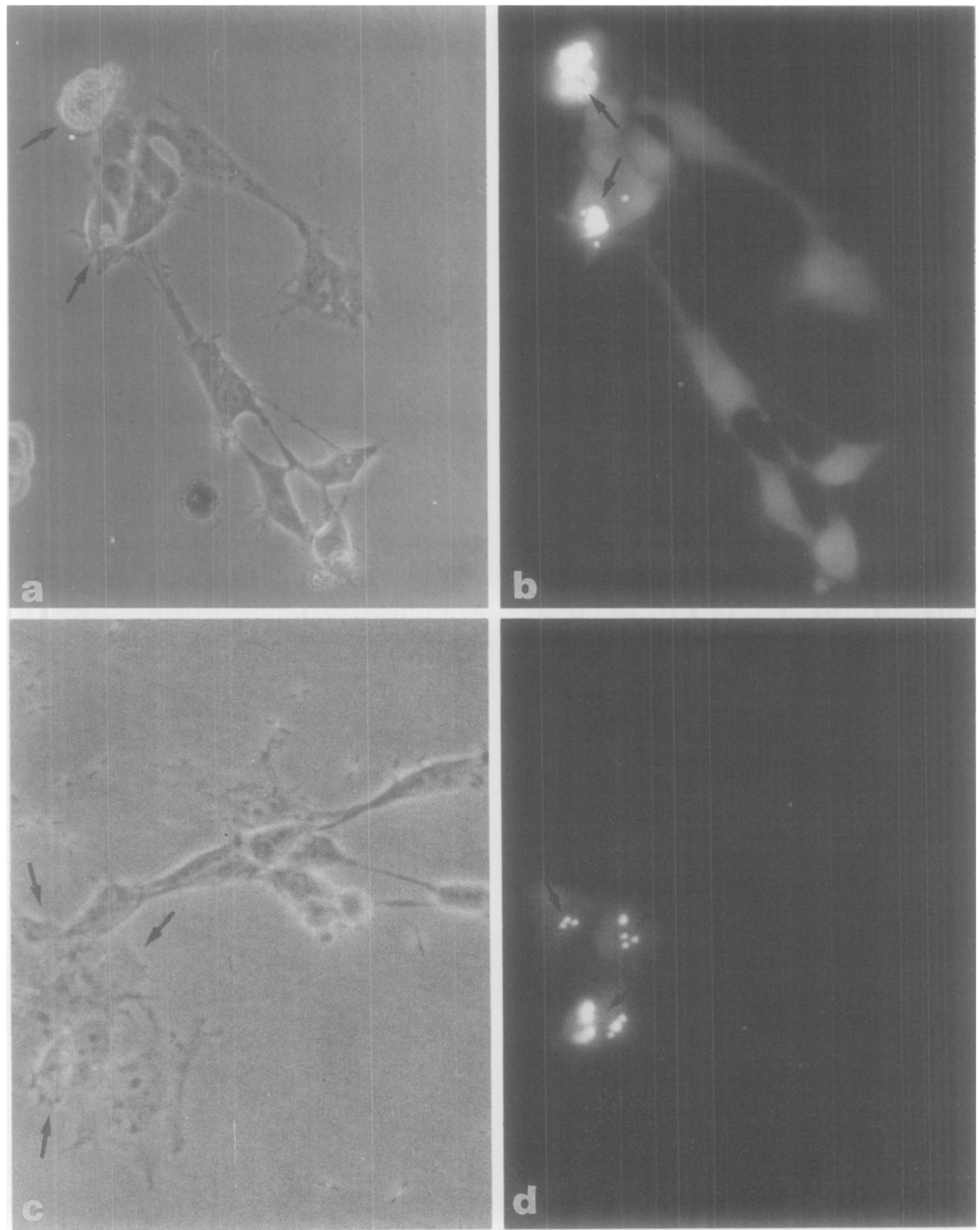

FIG. 4. Fluorescent dye transfer using 5(and 6)-carboxy-2,7-dichlorofluorescein diacetate (CDCFDA). Dye transfer was indicated by the observation of dye in touching bead-labeled donors (arrows) and nonbead-labeled recipients, as seen in the solvent control culture in (a) phase contrast and (b) dark field. No dye transfer is evident in the example shown in (c) phase contrast and (d) dark field, cells exposed to $5 \mu \mathrm{g}$ dieldrin/ml. ×25l. 
TABLE 1

TRANSFER OF $\left[{ }^{3} \mathrm{H}\right]$ URIDINE NUCLEOTIDE IN Cultures Exposed to Dieldrin

\begin{tabular}{lccccc}
\hline & \multicolumn{5}{c}{ Dieldrin $(\mu \mathrm{g} / \mathrm{ml})$} \\
\cline { 2 - 6 } & 0 & 3 & 5 & 7 & 11 \\
\hline Experiment 1 & $99^{a}$ & 98 & $91^{b}$ & $5^{b}$ & $1^{b}$ \\
Experiment 2 & 100 & 99 & $92^{b}$ & $8^{b}$ & $0^{b}$ \\
\hline
\end{tabular}

${ }^{a}$ Each value is the total number of positive transfers scored in 100 cell pairs.

${ }^{b}$ Significantly different from controls $(p<0.001)$.

even under conditions of incomplete inhibition. These assays may therefore be preferred for investigations in which it is critical to determine the presence of any gap junctional communication.

While each of these procedures provides a measure of junctional communication, the techniques may assess different aspects of this phenomenon. The gap junction protein has a half-life in the range of $2-10 \mathrm{hr}$ in liver cells

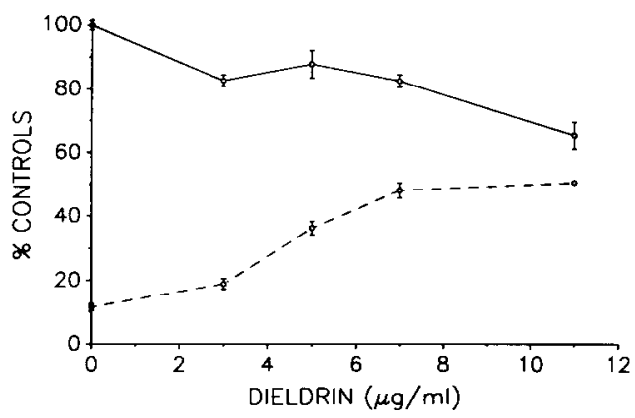

Fig. 5. Decreased cell survival (solid line) was observed at 7 and $11 \mu \mathrm{g}$ dieldrin $/ \mathrm{ml}$. Inhibition of metabolic coupling is suggested by the increased recovery of $6-\mathrm{TG}^{\mathrm{r}}$ cells (dashed line) observed at 7 and $11 \mu \mathrm{g}$ dieldrin/ml; however, this interpretation may be confounded by the cytotoxicity at these concentrations (see text). Data are expressed as the mean percentage control \pm SEM. The SEMs of the $0 \mu \mathrm{g} / \mathrm{ml}$ groups were 1.48 and 1.12 for the cell survival and metabolic coupling experiments, respectively. The SEM of the $11 \mu \mathrm{g} / \mathrm{ml}$ group in the metabolic coupling experiment was 1.06 . There were eight dishes per group.

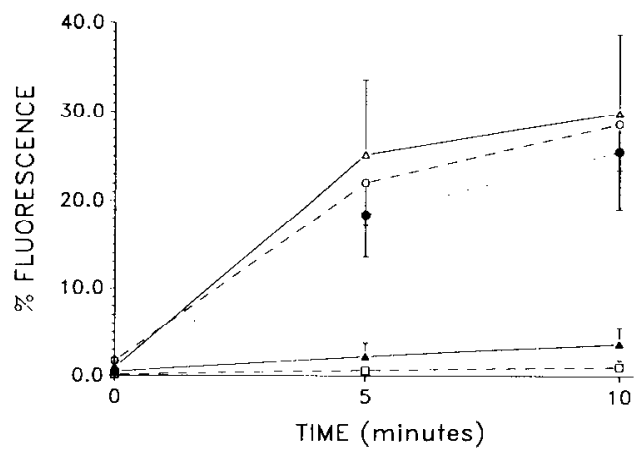

FIG. 6. Fluorescence return after photobleaching (FRAP) in cultures exposed to 0 (open circles), 3 (closed circles), 5 (open triangles), 7 (closed triangles), or 11 (open squares) $\mu \mathrm{g}$ dieldrin $/ \mathrm{ml}$. Fluorescence intensity was determined prior to and immediately after photobleaching, and at 5 and $10 \mathrm{~min}$ after photobleaching in cells in contact with other cells. The data are expressed as the means \pm SEM of the percentage of the prebleach value. Although a significant concentration effect was determined (Kruskal-Wallis statistic, $p<0.05$ ), no statistically significant differences were detceted between any of the dieldrin-exposed groups and controls.

(Yancey et al., 1981; Traub et al., 1983; Revel et al., 1984; Willecke et al., 1988), suggesting that the communicating channels themselves may be highly dynamic structures. However, since our exposures in the scrape-loading and FRAP experiments used established cultures and the exposures were only for $1 \mathrm{hr}$, the primary effect measured with these assays was most likely inhibition of previously formed channels. In contrast, since the CDCFDA, $\left[{ }^{3} \mathrm{H}\right]$ uridine, and 6-TG assays required replating of cells and, consequently, the formation of new communicating gap junctions, the responses measured by these assays may primarily reflect impairment of the establishment of junctional communication.

Because of differences in the experimental procedures, it was not possible to use the same length of exposure to dieldrin in each assay. Limitation of the exposure to $1 \mathrm{hr}$ with the FRAP assay was based on practical considerations necessary for controlling day-today variations in culture conditions and instrument sensitivity. Since the assay required 20-30 min to analyze each field, it was neces- 
sary to limit the exposure to a reasonable duration. The scrape-loading experiments were performed with $1 \mathrm{hr}$ cxposurcs to allow comparison to the FRAP assay. With the CDCFDA and $\left[{ }^{3} \mathrm{H}\right]$ uridine assays, the exposure duration was determined by the amount of time required for the cells to attach, spread, and form communicating junctions $(2.5 \mathrm{hr})$. The 3-day exposure with the 6-TG metabolic coupling assay allowed consistency with the procedure as previously published (Yotti et al., 1979; Trosko et al., 1985; Kavanagh et al., 1986; Zhong-Xiang et al., 1986); additionally, exposure durations of 1 or $2.5 \mathrm{hr}$ were difficult to control and execute due to the nature of the assay. An additional difference between the assays is that the scrapeloading assay required confluent cultures, while the other assays required nonconfluent cultures.

In this comparison of assays, scrape-loading was the most sensitive, discriminating, rapid, and inexpensive one to perform. Additionally, the newly developed CDCFDA assay demonstrated several advantages compared to the $\left[{ }^{3} \mathrm{H}\right]$ uridine, 6-TG metabolic coupling, and FRAP assays. While most similar to the $\left[{ }^{3} \mathrm{H}\right]$ uridine assay, the CDCFDA assay was much less expensive and time-consuming to perform since it relied on the transfer of a fluorescent dye instead of radiolabel; this eliminated necessary precautions for radiation hazards, as well as the added effort, time, and expense of autoradiography. Compared to the metabolic coupling assay, the CDCFDA assay was also easier, faster, and less expensive, since it required fewer and smaller cultures and can be completed in a few hours instead of requiring many days. The variability encountered with the FRAP assay was high compared to that of the CDCFDA and other assays, most likely resulting from factors difficult to control, including the concentration of fluorescent dye in neighboring cells, the number of contacting cells, uncontrolled photobleaching, and changes in instrument sensitivity. Additionally, because the FRAP assay is dependent on image analy- sis instrumentation, the CDCFDA assay has the advantage of requiring only a fluorescence microscope.

Previously published reports have shown that the FRAP, 6-TG metabolic coupling, $\left[{ }^{3} \mathrm{H}\right]$ uridine nucleotide transfer, and scrapeloading assays can be applied to various cell types. Similarly, we have successfully applied the CDCFDA dye transfer assay to several different cell types in our laboratory, including uterine cell lines and human embryonic palatal mesenchyme cells. However, not all cells are easy to work with in each assay, and in this case, as well as when verification with a second assay is desired, the newly developed CDCFDA assay may be a sensitive, inexpensive, and rapid alternative. Since the scrapeloading and CDCFDA assays are easily applied to embryonic cells, they may be particularly useful for studying alteration of gap junctional communication by developmental toxicants.

\section{ACKNOWLEDGMENTS}

This work was supported by grants from CDC/NIOSH (OH-00059), NIH (ES-04424), and The University of Michigan to R.L.-C. and predoctoral training grants (NIH GM-07767 and ES-07062) to D.J. The authors thank Isabel Corcos and Robert Zidell for technical assistance with the FRAP and CDCFDA techniques, respectively, Suzan Cull and Julie Baynton for secretarial assistance, Brian Stockhoff for assistance with data analysis, and Dave Hunsche and Mary Weed for preparation of graphs and photographs.

\section{REFERENCES}

Bevilacqua, A.. Loch-Caruso, R., AND ERICKSON, R. P. (1990). Abnormal development and dye coupling produced by antisense RNA to gap junction protein in mouse preimplantation embryos. Proc. Natl. Acad. Sci. USA 86, 5444-5448.

Blennerhassett, M. G., and Caveney, S. (1984). Separation of developmental compartments by a cell type with reduced junctional permeability. Nature (London) 309, 361-364.

Bruning, J. W., Kardol, M. J., ARENTZEN, R., NAlPal, A., AND VAN Der POEL, J. J. (1979). Carboxyfluorescein fluorochromasis assays for cell-mediated 
lympholysis (CML) and antibody-dependent cellular cytotoxicity (ADCC): A nonradioactive technique. Transplant. Proc. 11, 1961-1963.

CHEN, T. R. (1977). In situ detection of mycoplasma contamination in cell cultures by fluorescent Hoechst 33258 stain. Exp. Cell Res. 104, 255-262.

ChernofF, N., Kavlock, R., Kathrein, J., DunN, J., and Haseman, J. (1975). Prenatal effects of dieldrin and photodicldrin in micc and rats. Toxicol. Appl. Pharmacol. 31, 302-308.

Dulbecco, R., AND VoGT, M. (1954). Plaque formation and isolation of pure cell lines with poliomyelitis viruses. J. Exp. Med. 199, 167-182.

EAGLE, H. (1959). Amino acid metabolism in mammalian cell cultures. Science $130,432-437$.

El-Fouly, M. H.. Trosko, J. E., and Chang, C. C. (1987). Scrape-loading and dye transfer: A rapid and simple technique to study gap junctional intercellular communication. Exp. Cell Res. 168, 422-430.

EVERITT, B. S. (1977). The Analysis of Contingency Tables, pp. 44-47. Wiley, New York.

Fraser, S. E., Green, C. R., Bode, H. R., and Gilula, N. B. (1987). Selective disruption of gap junctional communication interferes with a patterning process in hydra. Science 237, 49-55.

GAD, S. C., AND WEIL, C. S. (1982). Statistics for Toxicologists. In Principles and Methods of Toxicology (A. W. Hayes, Ed.), pp. 273-320. Raven Press, New York.

GoOdall, H., and Johnson, M. H. (1982). Use of carboxyfluorescein diacetate to study formation of permeable channels between mouse blastomeres. Nature (London) 295, 524-526.

Hollander, M., AND Wolfe, D. A. (1973). Nonparametric Statistical Methods, pp. 114-137. Wiley, New York.

Huberman, E., MCKeown, C. K., Jones, C. A., HofFMAN, D. R., AND MURAO, S.-I. (1984). Induction of mutations by chemical agents at the hypoxanthineguanine phosphoribosyl transferase locus in human epithelial teratoma cells. Mutat. Res. 130, 127-137.

Jackson, P. R. Pappas, M. G., and Hansen, B. D. (1985). Fluorogenic substrate detection of viable intracellular and extracellular pathogenic protozoa. Science 227, 435-438.

JARNAGIN, J. L., AND LUCHSINGER, D. W. (1980). The use of fluorescein diacetate and ethidium bromide as a stain for evaluating viability of mycobacteria. Stain Technol. 55, 253-258.

JONES, K. H., AND SENFT, J. A. (1985). An improved method to determine cell viability by simultaneous staining with fluorescein diacetate-propidium iodide. J. Histochem. Cytochem. 33, 77-79.

Kavanagh, T. J., Chang, C.-C., and Trosko, J. E. (1986). Characterization of a human teratocarcinoma cell assay for inhibitors of metabolic cooperation. Cancer Res. 46, 1359-1366.
Kolber, M. A., Quinones, R. R., Gress, R. E., AND HENKART, P. A. (1988). Measurement of cytotoxicity by target cell release and retention of the fluorescent dye bis-carboxyethyl-carboxyfluorescein (BCECF). $J$ Immunol. Methods 108, 255-264.

LeE, S., Gilula, N. B., AND Warner, A. E. (1987). Gap junctional communication and compaction during preimplantation stages of mouse development. Cell 51, 851-860.

Lo, C. W., AND Gilula, N. B. (1979). Gap junctional communication in the preimplantation mouse $\mathrm{em}$ bryo. Cell 18, 399-409.

Loch-CARUSO, R., AND TROSKo, J. E. (1985). Inhibited intercellular communication as a mechanistic link between teratogenesis and carcinogenesis. Crit. Rev. Toxicol. 16, 157-183.

LOEWENSTEIN, W. R. (1979). Junctional intercellular communication and the control of growth. Biochim. Biophys. Acta 560, 1-65.

MCGinnes, K., Chapman, G,, Marks, R., AND PENNy, R. (1986). A fluorescence NK assay using flow cytometry. J. Immunol. Methods 86, 7-15.

Mosser, D. D., AND Bols, N. C. (1982). The effect of phorbols on metabolic cooperation between human fibroblasts. Carcinogenesis 3, 1207-1212.

OtTolenghi, A., IIASEMAn, J., AND SugGs, F. (1974). Teratogenic effects of aldrin, dieldrin, and endrin in hamsters and mice. Teratology 9, 11-16.

PITTS, J. D., AND SIMMS, J. W. (1977). Permeability of junctions between animal cells. Intercellular transfer of nucleotides but not of macromolecules. Exp. Cell Res. 104, 153-163.

Revel, J.-P., Nicholson, B. J., AND YANCEY, S. B. (1984). Molecular organization of gap junctions. Fed. Proc. 43, 2672-2677.

Rotman, B., AND Papermaster, B. W. (1966). Membrane properties of living mammalian cells as studied by enzymatic hydrolysis of fluorogenic esters. Proc. Natl. Acad. Sci. USA 55, 134-141.

STEWART, W. W. (1978). Functional connections between cells as revealed by dye-coupling with a highly fluorescent naphthalimide tracer. Cell 14, 741-759.

Suter, S., Trosko, J. E., El-Fouly, M. H., LockwOOD, L. R., AND KOESTNER, A. (1987). Dieldrin inhibition of gap junctional intercellular communication in rat glial cells as measured by the fluorescence photobleaching and scrape loading/dye transfer assays. Fundam. Appl. Toxicol. 9, 785-794.

Traub, O., Druge, P. M., AND Willecke, K. (1983). Degradation and resynthesis of gap junction protein in plasma membranes of regenerating liver after partial hepatectomy or cholestasis. Proc. Natl. Acad. Sci. USA 80, 755-759.

Trosko, J. E., Jone, C.. AYlsworth, C., AND Chang, C.-C. (1985). In vitro assay to detect inhibitors of intercellular communication. In Handbook of Carcinogen 
Testing (H. A. Milman and E. K. Weisburger, Eds.), pp. 421-437. Noyes, Park Ridge, NJ.

Wade, M. H., Trosko, J. E., AND SChindler, M. (1986). A fluorescence photobleaching assay of gap junction-mediated communication between human cells. Science 232, 525-528.

WARner, A. E., GuThrie, S. C., AND Gilula, N. B. (1984). Antibodies to gap-junctional protein selectively disrupt junctional communication in the early amphibian embryo. Nature (London) 311, 127-131.

Warner, A. E., And Lawrence, P. A. (1982). Permeability of gap junctions at the segmental border in insect epidermis. Cell 28, 243-252.

WEIR, M. P., AND Lo, C. W. (1982). Gap junctional communication compartments in the Drosophila wing disk. Proc. Natl. Acad. Sci. USA 79, 32323235 .

WeIR, M. P., AND Lo, C. W. (1984). Gap-junctional communication compartments in the Drosophila wing imaginal disk. Dev. Biol. 102, 130-146.

Welsch, F., Stedman, D. B., and Carson, J. L. (1987). Teratogen Interference with cell interactions: Cell-to-cell channel disruption as a potential mechanism of abnormal development. In Approaches to Elu- cidate Mechanisms in Teratogenesis (F. Welsch, Ed.), pp. 233-254. Hemisphere, New York.

Willecke, K., Traub, O., LoOK, J., STUTenkemPer, R., AND DERMIETzEL, R. (1988). Different protein components contribute to the structure and function of hepatic gap junctions. In Gap Junctions (E. L. Hertzberg and R. G. Johnson, Eds.), pp. 41-52. A. R. Liss, New York.

YanCEY, S. B., Nicholson, B. J., AND Revel, J.-P. (1981). The dynamic state of liver gap junctions. J. Supramol. Struct. Cell Biochem. 16, 221-232.

YotTi, L. P., Chang, C. C., And Trosko, J. E. (1979). Elimination of metabolic cooperation in Chinese hamster cells by a tumor promoter. Science 206, 1089 1091.

Zeuthen, J., Norgaard, J. O. R., Avner, P.. FelLOUS, M., WARTIOVAara, J., VAhERI, A., Rosen, A., AND GIOVANELla, B. C. (1980). Characterization of a human ovarian teratocarcinoma-derived cell line. Int. J. Cancer 25, 19-32.

Zhong-Xiang, L., Kavanagh, T.. Trosko, J. E.. AND CHANG, C. C. (1986). Inhibition of gap junctional intercellular communication in human teratocarcinoma cells by organochlorine pesticides. Toxicol. Appl. Pharmacol. 83, 10-19. 